\begin{tabular}{|c|c|c|}
\hline & Int.J.Curr.Microbiol.App.Sci (2021) 10(10): 363-368 & \\
\hline & $\begin{array}{l}\text { International Journal of Current Microbiology and Applied Sciences } \\
\text { ISSN: 2319-7706 Volume } \mathbf{1 0} \text { Number } \mathbf{1 0}(\mathbf{2 0 2 1 )} \\
\text { Journal homepage: } \underline{\text { http://www.ijcmas.com }}\end{array}$ & 30 \\
\hline $\begin{array}{l}\text { EXCELLENT } \\
\text { PUBLISHERS }\end{array}$ & & \\
\hline
\end{tabular}

\title{
Standardization of Growing Media for Ornamental Plant Species Grown in a Vertical Garden System in Assam
}

\author{
Madhusree Ghosh* and Madhumita Choudhury Talukdar
}

Department of Horticulture, Assam Agricultural University, Jorhat-785013, Assam, India

*Corresponding author

\section{A B S T R A C T}

\section{Keywords}

Vertical Garden,

Growing Media,

Plant species,

Soil, Cocopeat

Article Info

Accepted:

15 September 2021

Available Online:

10 October 2021
An experiment was carried out with an aim to standardize the growing media for five ornamental plant species in a vertical garden system in the Department of Horticulture, Assam Agricultural University, Jorhat, Assam. The experiment was laid out in a completely randomized block design with three replications, comprising of five ornamental plant species grown in five different media compositions. The experiment was conducted to study the influence of soil, vermicompost, cocopeat and sand on the plant species in the vertical garden system. The five different media compositions under study were $\mathrm{M}_{1}:$ soil + cocopeat + vermicompost + sand $(3: 0.25$ : $1: 1.5), \mathrm{M}_{2}:$ soil + cocopeat + vermicompost + sand $(2.5: 0.5: 1.5: 1.25), \mathrm{M}_{3}:$ soil + cocopeat + vermicompost + sand $(2: 0.75: 2: 1), \mathrm{M}_{4}:$ soil + cocopeat + vermicompost + sand $(1.5: 1: 2.5: 0.75)$ and $\mathrm{M}_{5}:$ Soil. The ornamental species selected were: $\mathrm{S}_{1}$ : Philodendron Ceylon (Philodendron erubescens 'Gold' K. Koch), $\mathrm{S}_{2}$ : Spider Plant (Chlorophytum comosum Variegatum (Thunb.)), $\mathrm{S}_{3}$ : Fern (Nephrolepis exaltata (L.) Schott), $\mathrm{S}_{4}$ : Moses-in-the-cradle (Rhoeo discolor Sw. (syn. Tradescantia spathacea)) and $\mathrm{S}_{5}$ : Baby Doll Cordyline (Cordyline compacta Purple (L.)). Among the five growing media compositions used, medium $\mathrm{M}_{3}$ : soil + cocopeat + vermicompost + sand $(2: 0.75: 2: 1)$ performed better in terms of all the growth parameters recorded in the five plants species in the vertical garden system.

\section{Introduction}

Vertical gardens, also known as Living Walls, are a form of garden that utilizes vertical spaces of walls and buildings, rather than consuming horizontal spaces as in conventional garden systems. Vertical gardens offer an alternative sustainable solution to the problem of reducing units of land area for landscaping or for agricultural purposes. It is a wall partially or completely covered with greenery that includes a growing media such as a soil or a substrate. This consist of covering the buildings, either indoors or outdoors, with plants capable of covering on their own or supported by some substructures. Essentially, vertical gardens and green façades are the two basic classifications 
of green walls. Green façades are primarily walls that are covered with climbing plants or cascading vegetation grown in the ground or large containers. On the other hand, vertical gardens or livings walls consist of pre- planted panels or vertical modules that hold growing media for supporting plant growth. These panels or modules are fixed vertically to a structural wall or frame. Stanley Hart White conceptualized the vertical garden and prototyped green wall systems in the backyard of his residence. He was a Professor of Landscape Architecture at the University of Illinois Urbana- Champaign, who patented the first- of- its- kind vertical garden named Botanical Brick in 1938. Patrick Blanc, a French Botanist, is credited as the father of modern vertical gardening. He developed the modern vertical gardens with the incorporation of hydroponics in 1988 at the Museum of Science and Industry in Paris.

Vertical gardens are the future of gardening as they promote the concept of sustainability. Lately, indoor air pollution has emerged as an important global health issue of urban areas in the 21 st century. Carbon monoxide, benzene, formaldehyde, nitrogen oxide, sulphur dioxide, ozone and others are some common air pollutants. Biomonitoring with the aid of plants such as Chlorophytum comosum, Dracaena reflexa and others prove to be a low cost and valuable solution towards the problem of indoor air pollution (Gawronska et al., 2015). Another serious problem in populous urban cities and towns is the "Urban Heat Island Effect", which refers to the significant increase in temperature of urban areas as compared to the surrounding rural areas. This usually arises due to the use of concrete and asphalt in construction of buildings. One of the most effective methods to combat this problem is to increase the vegetation cover in the urban areas and vertical gardens provide just the right solution, as these gardens increase vegetation without consuming horizontal spaces. These gardens have also proved to be a boon for the stressedfilled lifestyle of people in urban areas. Moreover, vertical gardens have also been observed to increase the property value in urban areas. Studies suggest that plants can increase property value up to $6-15 \%$ (Gilhooley 2002; Peck et al., 1999). Vertical gardens also offer employment opportunities to landscape architectures or nurserymen.

\section{Materials and Methods}

A vertical garden, for the study, was constructed on the ground floor of the fourstorey building of the Department of Horticulture of Assam Agricultural University, Jorhat. The site is located at $26^{\circ} 47^{\prime} \mathrm{N}$ latitude and $94^{\circ} 12^{\prime} \mathrm{E}$ longitude at an elevation of $86.8 \mathrm{~m}$ above mean sea level. The vertical garden modules consisted of frames or supporting panel and easily detachable pots, made of recycled poly propylene material. The supporting panel was fixed on the wall of the building vertically using screws and bolts. The panel had curvatures to attach the pots. The pots were shaped like troughs, having wide open top and tapering to a $\mathrm{v}$ - shape at the bottom. The pots had two drainage holes, so that water from the topmost pot fell in the pot just bottom of it and so on. The pots were readily removable for planting purposes and also for simplifying the arrangement of the vertical garden. The vertical garden consisted of 225 pots ( 75 pots per replication) hanged in a polypropylene frame attached to the wall of the building indoors. The size of the vertical garden was $9.69 \mathrm{~m}^{2}(2.03 \mathrm{~m} \mathrm{x} 4.778 \mathrm{~m})$. The average temperature of $22.71{ }^{\circ} \mathrm{C}$ and the average relative humidity of $80.5 \%$ were recorded inside the building. The light intensity ranged from 2200-4380 lux at the site of the experiment.

The experiment was conducted with 25 numbers of treatments comprising of five 
ornamental foliage plant species and five different growing media having different compositions by volume. The growing media consisted of soil, cocopeat, vermicompost and sand in various proportions. As such, the media compositions used in the vertical garden were : $\mathrm{M}_{1}$ : soil + cocopeat + vermicompost + sand ( $3: 0.25: 1: 1.5), \mathrm{M}_{2}$ : soil + cocopeat + vermicompost + sand $(2.5$ : $0.5: 1.5: 1.25), \mathrm{M}_{3}:$ soil + cocopeat + vermicompost + sand $(2: 0.75: 2: 1), \mathrm{M}_{4}$ : soil + cocopeat + vermicompost + sand (1.5: $1: 2.5: 0.75)$ and $\mathrm{M}_{5}$ : Soil. The ornamental plant species grown in the vertical garden system were namely $S_{1}$ : Philodendron Ceylon (Philodendron erubescens 'Gold' K. Koch), $\mathrm{S}_{2}$ : Spider Plant (Chlorophytum comosum Variegatum (Thunb.)), $\mathrm{S}_{3}$ : Fern (Nephrolepis exaltata (L.) Schott), $\mathrm{S}_{4}$ : Moses-in-the-cradle (Rhoeo discolor Sw. (syn. Tradescantia spathacea)) and $\mathrm{S}_{5}$ : Baby Doll Cordyline (Cordyline compacta Purple (L.)). The experiment was designed in completely randomized design (CRD) with three replications. Vegetative parameters like plant height, plant diameter, leaf number, leaf area, root number and root length were recorded for a period of two years for study. The $\mathrm{pH}$, water holding capacity, porosity and available NPK content of the growing media were also recorded (Table. 1). The statistical analysis of data was computed by the standard statistical procedures given by Panse and Sukhatme (1967).

\section{Results and Discussion}

Plant height and leaf number are important parameters which characterizes the features of indoor ornamental plants. The highest plant heights of the five species were recorded in growing media $\mathrm{M}_{3}$ (soil + cocopeat + vermicompost + sand $(2: 0.75: 2: 1)$ ). This may be attributed to the physico- chemical properties of the growing medium $\mathrm{M}_{3}$ which consisted of near neutral $\mathrm{pH}$ of $6.58,47.42 \%$ total porosity, $34.44 \%$ water holding capacity. The presence of vermicompost in ample amounts added enough organic matter to the growing medium. On the other hand, minimum plant heights were recorded in medium $\mathrm{M}_{5}$ (soil), i.e., the control. This may be due to the lower available nutrient status of the growing medium.

The canopy diameters of $35.06 \mathrm{~cm}, 23.47 \mathrm{~cm}$, $21.60 \mathrm{~cm}, 24.70 \mathrm{~cm}$ and $17.63 \mathrm{~cm}$ were recorded highest in Philodendron, Spider plant, Ferns, Moses-in-the-cradle and Baby Doll Cordyline grown in media $\mathrm{M}_{3}$. The increase in canopy diameters might be attributed to the high nitrogen levels in the medium $\mathbf{M}_{3}$. Nitrogen content is linked to carbohydrate utilization and enhanced protein synthesis which increases rate of metabolism, cell division, cell elongation; thereby promoting apical growth and plant spread (Verma et al., 1996).

Total number of leaves for the five species was found to be maximum in plants grown in medium $\mathrm{M}_{3}$, showing 12.00, 21.33, 22.67, 30.00 and 36.13 number of leaves in Philodendron, Spider plant, Ferns, Moses-inthe-cradle and Baby Doll Cordyline, respectively. Higher number of leaves might be due to ample aeration provided by sand and the nutrient status made available by both vermicompost and cocopeat. Similar results were reported by Moghadam et al., (2012) in Asiatic lilium hybrid 'Navona'.

Leaf area determines the ability of a plant to trap solar energy utilized for photosynthetic activities. Highest leaf area recorded in medium $\mathrm{M}_{3}$ could be due to the improved leaf growth in terms of leaf number, length and width. 
Table.1 Properties of the growing media

\begin{tabular}{|c|c|c|c|c|c|c|}
\hline Medium & $\begin{array}{c}\text { Water } \\
\text { Holding } \\
\text { Capacity }\end{array}$ & $\begin{array}{c}\text { Total } \\
\text { Porosity }\end{array}$ & $\mathbf{p H}$ & $\begin{array}{c}\text { Available } \\
\mathbf{N}(\mathbf{\%})\end{array}$ & $\begin{array}{c}\text { Available } \\
\mathbf{P}(\boldsymbol{\%})\end{array}$ & $\begin{array}{c}\text { Available } \\
\text { K (\%) }\end{array}$ \\
\hline $\mathbf{M}_{\mathbf{1}}$ & 36.73 & 45.20 & 6.430 & 0.048 & 0.025 & 0.127 \\
\hline $\mathbf{M}_{\mathbf{2}}$ & 33.01 & 46.00 & 6.470 & 0.044 & 0.022 & 0.129 \\
\hline $\mathbf{M}_{\mathbf{3}}$ & 34.44 & 47.42 & 6.580 & 0.051 & 0.031 & 0.136 \\
\hline $\mathbf{M}_{\mathbf{4}}$ & 38.68 & 50.00 & 6.520 & 0.057 & 0.035 & 0.142 \\
\hline $\mathbf{M}_{\mathbf{5}}$ & 41.00 & 40.83 & 5.800 & 0.023 & 0.016 & 0.119 \\
\hline
\end{tabular}

Table.2 Effect of growing media on different characters of the plant species

\begin{tabular}{|c|c|c|c|c|c|c|}
\hline Treatments & $\begin{array}{c}\text { Plant } \\
\text { Height } \\
\text { (cm) }\end{array}$ & $\begin{array}{c}\text { Plant } \\
\text { Diameter } \\
(\mathbf{c m})\end{array}$ & $\begin{array}{c}\text { Leaf } \\
\text { Number }\end{array}$ & $\begin{array}{c}\text { Leaf } \\
\operatorname{Area}\left(\mathrm{cm}^{2}\right)\end{array}$ & $\begin{array}{c}\text { Root } \\
\text { number }\end{array}$ & $\begin{array}{c}\text { Root } \\
\text { Length } \\
\text { (cm) }\end{array}$ \\
\hline $\mathbf{M}_{1} \mathbf{S}_{1}$ & 19.03 & 19.27 & 8.76 & 80 & 9.16 & 14.47 \\
\hline $\mathbf{M}_{2} \mathbf{S}_{1}$ & 21.40 & 20.36 & 9.97 & 87.33 & 10.33 & 15.66 \\
\hline $\mathbf{M}_{3} \mathbf{S}_{1}$ & 25.17 & 23.47 & 12.00 & 89.16 & 11.73 & 16.63 \\
\hline $\mathbf{M}_{4} \mathbf{S}_{1}$ & 17.83 & 17.65 & 7.66 & 59.67 & 10.20 & 12.80 \\
\hline $\mathbf{M}_{5} \mathbf{S}_{1}$ & 13.37 & 17.46 & 6.33 & 48.33 & 7.967 & 12.20 \\
\hline $\mathbf{M}_{1} \mathbf{S}_{2}$ & 20.65 & 27.10 & 16.17 & 44.96 & 10.90 & 6.50 \\
\hline $\mathbf{M}_{2} \mathbf{S}_{2}$ & 22.13 & 30.41 & 18.67 & 46.88 & 14.23 & 7.23 \\
\hline $\mathbf{M}_{3} \mathbf{S}_{2}$ & 26.76 & 35.06 & 21.33 & 47.83 & 15.93 & 7.60 \\
\hline $\mathbf{M}_{4} \mathbf{S}_{2}$ & 16.87 & 26.83 & 13.00 & 34.00 & 11.80 & 6.40 \\
\hline $\mathbf{M}_{5} \mathbf{S}_{2}$ & 12.40 & 19.81 & 10.50 & 30.30 & 8.600 & 5.60 \\
\hline $\mathbf{M}_{1} \mathbf{S}_{3}$ & 18.06 & 18.97 & 17.50 & 53.90 & 22.80 & 14.06 \\
\hline $\mathbf{M}_{2} \mathbf{S}_{3}$ & 20.00 & 19.20 & 19.00 & 61.00 & 31.67 & 18.37 \\
\hline $\mathbf{M}_{\mathbf{3}} \mathbf{S}_{\mathbf{3}}$ & 21.86 & 21.60 & 22.67 & 68.73 & 32.83 & 19.40 \\
\hline $\mathbf{M}_{\mathbf{4}} \mathbf{S}_{3}$ & 14.93 & 18.93 & 14.00 & 48.76 & 26.67 & 16.96 \\
\hline $\mathbf{M}_{5} \mathbf{S}_{3}$ & 12.47 & 15.67 & 8.93 & 40.33 & 18.77 & 11.40 \\
\hline $\mathbf{M}_{1} \mathbf{S}_{4}$ & 24.47 & 19.01 & 24.67 & 65.60 & 13.33 & 10.90 \\
\hline $\mathrm{M}_{2} \mathrm{~S}_{4}$ & 28.07 & 21.40 & 27.50 & 74.10 & 15.73 & 11.37 \\
\hline $\mathbf{M}_{3} \mathbf{S}_{4}$ & 31.33 & 24.70 & 30.00 & 83.52 & 17.30 & 12.50 \\
\hline $\mathbf{M}_{4} \mathbf{S}_{4}$ & 22.25 & 18.10 & 20.00 & 59.46 & 14.30 & 9.50 \\
\hline $\mathbf{M}_{5} \mathbf{S}_{4}$ & 16.89 & 17.00 & 17.167 & 47.23 & 13.26 & 7.97 \\
\hline $\mathbf{M}_{1} \mathbf{S}_{5}$ & 19.88 & 16.43 & 29.67 & 43.27 & 47.01 & 20.73 \\
\hline $\mathbf{M}_{2} \mathbf{S}_{5}$ & 20.70 & 16.97 & 33.97 & 55.73 & 52.56 & 23.76 \\
\hline $\mathbf{M}_{3} \mathbf{S}_{5}$ & 21.61 & 17.63 & 36.13 & 57.46 & 53.33 & 25.53 \\
\hline $\mathbf{M}_{4} \mathbf{S}_{5}$ & 18.83 & 12.47 & 27.67 & 38.88 & 50.03 & 17.73 \\
\hline $\mathbf{M}_{5} \mathbf{S}_{5}$ & 16.97 & 12.35 & 25.57 & 26.90 & 41.97 & 15.90 \\
\hline $\operatorname{S.Ed}( \pm)$ & 0.65 & 0.73 & 0.53 & 0.64 & 0.71 & 0.48 \\
\hline C.D $(5 \%)$ & 1.30 & 1.48 & 1.05 & 1.30 & 1.43 & 0.98 \\
\hline
\end{tabular}


Better performance of the medium $\mathrm{M}_{3}$ over $\mathrm{M}_{5}$ could be due to the addition of cocopeat and vermicompost, which improved the physical and nutrient status of the growing media. Similar effects were reported by Nikrazm et al., (2011).

Growth and development of roots is directly correlated to the total biomass of the plant. Improved root system could be associated with the production of more number of leaves, as reported by Tonutti and Giulivo (1990).

This could also be seen in the current investigation, where the number roots in Philodendron, Spider plant, Ferns, Moses-inthe-cradle and Baby Doll Cordyline were maximum in growing medium, $\mathbf{M}_{3}$ (and was at par with $\mathrm{M}_{2}$ ) and minimum in medium $\mathrm{M}_{5}$.

The longest roots in the five species were recorded in medium $\mathrm{M}_{3}$, which were at par with $\mathrm{M}_{2}$; whereas the shortest were recorded in medium $\mathrm{M}_{5}$.

Cocopeat provided a better texture to the growing media and also prevented compaction. Maximum root length and number in medium $\mathrm{M}_{3}$ might be due to the presence of higher percentage of available phosphorus and soil texture of the growing media. Similar results were obtained by Kavipriya et al., (2019) in Dracaena reflexa "Variegata".

From the present findings, it can be inferred that all the five species performed best in growing media composition $\mathrm{M}_{3}$ comprising of soil + cocopeat + vermicompost + sand in the ratio of 2: 0.75: 2: 1 by volume, followed by medium $\mathrm{M}_{2}$ (soil + cocopeat + vermicompost + sand $(2.5: 0.5: 1.5: 1.25))$ in terms of their growth parameters. Hence medium $\mathrm{M}_{3}$ could be considered ideal for vertical gardening under Assam condition.

\section{References}

Gawrońska, H. and Bakera, B. (2015). Phytoremediation of particulate matter from indoor air by Chlorophytum comosum L. plants. Air Qual Atmos Health. 8(3): 265-272.

Gilhooley, M. (2002). Green green grass of work: a little bit of green can go a long way, and we aren"t talking about money. Facilities Design and Management. http://www.iuoe.org.

Kavipriya, M. V., Sankari, A. and Jegadeswari, D. (2019). Studies on the Effect of Alternate Media on Growth of "Dracaena reflexa „Variegata"e. Int. J. Curr. Microbiol. Appl. Sci. 8(02): 3394-3400.

Moghadam, A. R. L., Ardebili, Z. O. and Saidi, F. (2012). Vermicompost induced changes in growth and development of Lilium Asiatic hybrid var. Navona. Afr. J. Agric. Res. 7(17): 2609-2621.

Nikrazm, R., Ajirlou, S. A., Khaligy, A. and Tabatabaei, S. J. (2011). Effects of different media on vegetative growth of two Lilium cultivars in soilless culture. J. Sci. Technol. of Greenhouse Culture. 2(6): $1-9$.

Panse, V. G. and Sukhatme, P. V. (1985). Statistical Methods for Agricultural Workers. Indian Council of Agricultural Research, New Delhi.

Peck, S. W., Callaghan, C., Kuhn, M. E., Arch, B. and Bass, B. (1999). Greenbacks from green roofs: Forging a new industry in Canada. Canada Mortgage and Housing Corporation. Ottawa, Canada.

Tonutti, P. and Giulivo, C. (1990). Effect of available soil volume on growth of young kiwi plants (1). Acta Hortic. 282: 283-290.

Verma, R. B., Singh, P. K. and Singh, S. B. (1996). Effect of nitrogen and potassium levels on growth, yield and nutrient uptake of Colocasia. J. of Root Crops. 22(2): 139-143. 


\section{How to cite this article:}

Madhusree Ghosh and Madhumita Choudhury Talukdar. 2021. Standardization of Growing Media for Ornamental Plant Species Grown in A Vertical Garden System in Assam. Int.J.Curr.Microbiol.App.Sci. 10(10): 363-368. doi: https://doi.org/10.20546/ijcmas.2021.1010.044 